\title{
Stanford falls in line on conflict of interest rules
}

San Francisco. Stanford University in California has rejected the advice of an advisory panel set up by its Office of Technology Licensing and changed its rules on intellectual property rights, making it no longer possible for individual faculty members to retain the rights to their inventions.

It has also resolved a contentious dispute over computer software by deciding that the university retains the rights to patented software, but that ownership of all copyrighted material will remain with the inventor. Both changes are part of a broad range of new conflict-of-interest rules approved by the university Senate on 14 April

Stanford has been one of the most successful US universities in generating income through the successful exploitation of university-based inventions; last year it earned over $\$ 25$ million in this way.

The new rules emerged from two years of study by a committee chaired by Craig Heller,

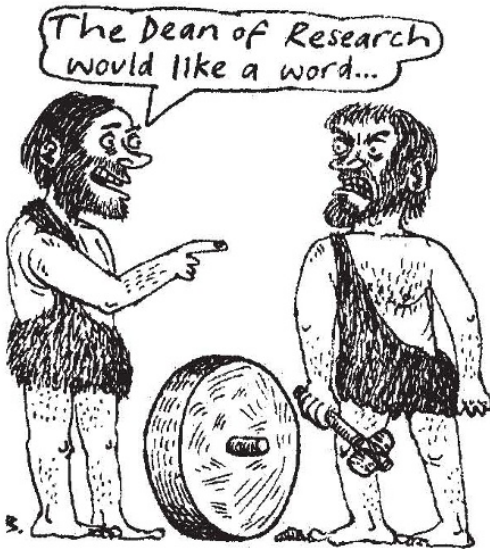

professor of biological sciences, to define faculty responsibility and pinpoint situations that compromise integrity.

Until now, a conflict-of-interest policy dating from 1966 had focused primarily on setting limits on the hours professors could engage in outside consultancy or other income-generating activities. But professors retained all intellectual property rights.

An early draft of the new rules allowed faculty to retain title to their inventions unless a government grant stated otherwise. The committee said at the time that it believed that the opportunity for entrepreneurship and financial reward helped to attract top researchers and promoted technology transfer to the commercial sector.

The licensing office's advisory panel had argued that giving individual scientists title to their inventions acted as a powerful incentive to them to seek ways of exploiting the results of their work.

But the committee later decided that such a policy generated conflicts of interest by putting faculty members in the position of deciding which source of support led to a particular invention. The university Senate has now decided to fall in line with most other US universities and to stipulate in its new rules that all discoveries will now remain the property of the university.

The new policy also requires professors to be frequently on campus and to commit their scholarly expertise, efforts and research primarily to Stanford. The provisions would prohibit professors from serving in a managerial role at companies and from acting as a principal investigator for research that could be done at Stanford.

Faculty members are allowed to own stock in outside companies and to sit on corporate boards of directors. In addition, deans at Stanford would be able to designate certain conflicts of interest as manageable.

Several elements of the policy anticipate guidelines expected to be published shortly by the National Institutes of Health and the National Science Foundation requiring institutional oversight of faculty financial relationships.

But the guidelines fall short of strict provisions at universities such as Harvard, which require advance approval for most financial connections between professors and commercial enterprises.

The new guidelines have been accepted because most faculty members recognized that universities were attracting outside scrutiny of their financial ties, and that there was a need for stronger rules at Stanford, according to Barton Bernstein, professor of history and a member of the committee.

"We didn't have rules to effectively guide faculty and to protect the university," says Bernstein, who argues that the intellectual property created by a university faculty member should be social property. "We didn't know whether egregious things were going on."

Charles Kruger, ex-officio dean of research who is also on the committee, said the guidelines would be unlikely to change existing outside relationships among faculty. But he said that they might limit gifts or other contributions from companies in which professors have a financial interest.

Katharine $\mathrm{Ku}$, director of Stanford's Office of Technology Licensing, said it was unclear how significant the impact of the policy - which committee members stress is not aimed at increasing university revenue - is likely to be on university income. She praised the change and said she did not feel that it would discourage faculty from encouraging the exploitation of their inventions.

\section{France backs off strict limits on embryo research}

Paris. By adding amendments to a proposed new law on bioethics, the French National Assembly has toned down harsh restrictions on research using human embryos and related aspects of human fertility which the Senate had voted for earlier this year.

Last week, the Assembly adopted by a large majority three separate bills that will make up the new law. It was the second reading of the bills by the Assembly, which was packed for the vote. The bills will now return to the Senate for a second reading, before becoming law.

The adopted bills would ban eugenics, genetic testing (except for research, medical or judicial purposes), surrogate motherhood and patenting of parts of the human body. The law would also restrict in vitro fertilization to living sterile couples of reproductive age. The bills would permit somatic gene therapy, but not germ-line therapy. Infringements would carry a fine of up to FFr2 million (US\$340,000), or prison.

All this has already been approved by the Senate. But the Assembly modified the senators' wish for a complete ban on preimplantation diagnosis and selection of embryos. In line with the opinion of many researchers and physicians (see Nature 367 , $209 ; 1994)$, it voted that such techniques should be permitted in "exceptional cases" where parents risked bearing a child with a "particularly serious" genetic disease.

Similarly, the Assembly subtly changed the Senate's ban on all embryo research that threatens the "integrity" of the embryo. Although it maintained the condition that the embryo should not be harmed, it stated that such research should be permitted for medical purposes; in practice, this would, for example, allow cells to be removed.

The Assembly also rejected both a requirement that embryos be implanted within eight days of fertilization, and a ban on the destruction of spare embryos - of which there are around 20,000 in France.

The bioethics bills would also amend the data protection act to allow physicians to provide biomedical researchers with confidential information about patients provided that patients agree and that their identity is concealed. Such data may not be used for international projects, unless the other countries involved have equivalent legislation.

Researchers wishing to use such data would have to apply to a new commission, appointed by the Ministry of Research and Higher Education, and the Commission Nationale de l'Informatique et des Libertés (CNIL). To speed up the process, the ministry would be required to make a ruling within one month, and the CNIL within two.

Declan Butler 